\title{
Global trends in extreme precipitation: climate models versus observations
}

\author{
B. Asadieh and N. Y. Krakauer \\ Civil Engineering Department and NOAA-CREST, The City College of New York, \\ City University of New York, New York, USA \\ Correspondence to: B. Asadieh (basadie00@ citymail.cuny.edu) \\ Received: 5 September 2014 - Published in Hydrol. Earth Syst. Sci. Discuss.: 15 October 2014 \\ Revised: - - Accepted: 9 January 2015 - Published: 12 February 2015
}

\begin{abstract}
Precipitation events are expected to become substantially more intense under global warming, but few global comparisons of observations and climate model simulations are available to constrain predictions of future changes in precipitation extremes. We present a systematic global-scale comparison of changes in historical (1901-2010) annualmaximum daily precipitation between station observations (compiled in HadEX2) and the suite of global climate models contributing to the fifth phase of the Coupled Model Intercomparison Project (CMIP5). We use both parametric and non-parametric methods to quantify the strength of trends in extreme precipitation in observations and models, taking care to sample them spatially and temporally in comparable ways. We find that both observations and models show generally increasing trends in extreme precipitation since 1901, with the largest changes in the deep tropics. Annual-maximum daily precipitation (Rx1day) has increased faster in the observations than in most of the CMIP5 models. On a global scale, the observational annual-maximum daily precipitation has increased by an average of $5.73 \mathrm{~mm}$ over the last 110 years, or $8.5 \%$ in relative terms. This corresponds to an increase of $10 \% \mathrm{~K}^{-1}$ in global warming since 1901 , which is larger than the average of climate models, with $8.3 \% \mathrm{~K}^{-1}$. The average rate of increase in extreme precipitation per $\mathrm{K}$ of warming in both models and observations is higher than the rate of increase in atmospheric water vapor content per $\mathrm{K}$ of warming expected from the Clausius-Clapeyron equation. We expect our findings to help inform assessments of precipitationrelated hazards such as flooding, droughts and storms.
\end{abstract}

\section{Introduction}

Trends in extreme meteorological events have received considerable attention in recent years due to the numerous extreme events such as hurricanes, droughts and floods observed (Easterling et al., 2000). Changes in global climate and alteration of Earth's hydrological cycle (Allen and Ingram, 2002; Held and Soden, 2006; Wentz et al., 2007) have resulted in increased heavy precipitation with consequent increased surface runoff and flooding risk (Trenberth, 1999, 2011), which is likely to continue in the future (Dankers et al., 2013). Anthropogenic climate change is expected to change the distribution, frequency and intensity of precipitation and result in increased intensity and frequency of floods and droughts, with damaging effects on the environment and society (Dankers et al., 2013; Field, 2012; Min et al., 2011; O'Gorman and Schneider, 2009; Solomon et al., 2007; Trenberth, 2011; Trenberth et al., 2003).

As a result of greenhouse gas (GHG) build-up in the atmosphere, global mean near-surface temperature shows an increasing trend since the beginning of the twentieth century (Angeles et al., 2007; Campbell et al., 2011; Singh, 1997; Solomon et al., 2007; Taylor et al., 2007), with greater increases in mean minimum temperature than in mean maximum temperature (Alexander et al., 2006; Peterson, 2002). The Fifth Assessment Report of the Inter-Governmental Panel on Climate Change (IPCC) indicates that, globally, near-surface air temperature has increased by approximately $0.78^{\circ} \mathrm{C}(0.72$ to 0.85$)$ since 1900 , with a greater trend slope in recent decades (Stocker et al., 2013).

As a result of global warming, climate models and satellite observations both indicate that atmospheric water vapor content has increased at a rate of approximately $7 \% \mathrm{~K}^{-1}$ warm- 
ing (Allen and Ingram, 2002; Held and Soden, 2006; Trenberth et al., 2005; Wentz et al., 2007), as expected from the Clausius-Clapeyron equation under stable relative humidity (Held and Soden, 2006; Pall et al., 2006). Increasing availability of moisture in the atmosphere can be expected to result in increased intensity of extreme precipitation (Allan and Soden, 2008; Allen and Ingram, 2002; O'Gorman and Schneider, 2009; Trenberth, 2011; Trenberth et al., 2003), with a proportionally greater impact than for mean precipitation (Lambert et al., 2008; Pall et al., 2006). An increase in the frequency and intensity of extreme precipitation has already been identified in observations (Alexander et al., 2006; Min et al., 2011; Solomon et al., 2007; Westra et al., 2013) as well as in simulations of climate models (Kharin et al., 2013; Scoccimarro et al., 2013; Toreti et al., 2013). Climate models also indicate that further increases in extreme precipitation would be expected over the next decades (Kharin et al., 2007, 2013; O'Gorman and Schneider, 2009; Pall et al., 2006; Toreti et al., 2013), while in terms of mean precipitation, moist regions become wetter and dry regions drier (Allan and Soden, 2008; Chou and Neelin, 2004; Wentz et al., 2007; Zhang et al., 2007).

Although climate models generally indicate an increase in precipitation and its extremes, the rate of this increase seems to be underestimated (Allan and Soden, 2008; Allen and Ingram, 2002; Min et al., 2011; O'Gorman and Schneider, 2009; Sillmann et al., 2013; Wan et al., 2013; Wentz et al., 2007; Zhang et al., 2007), which implies that future projections of changes in precipitation extremes may also be underpredicted (Allan and Soden, 2008). This underestimation can be a result of differences in scale between climate model grids and observational data (Chen and Knutson, 2008; Sillmann et al., 2013; Toreti et al., 2013; Wan et al., 2013; Zhang et al., 2011) and/or limitations in moist convection or other parameterizations in the models (O'Gorman and Schneider, 2009; Wilcox and Donner, 2007). Assessments of climate models also reveal that the rate of increase in precipitation extremes varies greatly among models, especially in tropical zones (Kharin et al., 2007; O'Gorman and Schneider, 2009), which makes it especially important to compare modeled trends with those identified in observations. However, few global comparisons of observations and climate model simulations are available to constrain predictions of future changes in precipitation extremes. Of the available globalscale studies, some use older versions of climate models or observations and/or use only one or a few climate models (Allan and Soden, 2008; Min et al., 2011; O'Gorman and Schneider, 2009; Wentz et al., 2007; Zhang et al., 2007). Spatial and temporal differences in data coverage between climate models and observations also challenge comparisons.

In this paper, we present a systematic comparison of changes in annual-maximum daily precipitation in weather station observations (compiled in HadEX2) with 15 models from the suite of global climate models contributing to the latest phase of the Coupled Model Intercomparison Project
(CMIP5) (Taylor et al., 2012), as the largest and most recent set of global climate model runs. Both parametric (linear regression) and non-parametric methods - Mann-Kendall (Appendix A1) as well as Sen's slope estimator (Appendix A2) are utilized to quantify the strength of trends in extreme precipitation in observations and models, taking care to sample them spatially and temporally in comparable ways. We also calculate the rate of change in the defined extreme precipitation index per $\mathrm{K}$ of global warming in both observations and models to investigate the relation between global warming and precipitation extremes. Climate models and observation data sets do not provide the same spatial and temporal coverage for precipitation data, leading to some uncertainties in the comparison of the results. In the present study, precipitation data for years/grids of climate models that do not have corresponding observational data are excluded, resulting in a comparable sampling approach for both data sets.

\section{Data and methodology}

Precipitation data in the Hadley Centre global land-based gridded climate extremes data set (HadEX2) is based on daily observations from about 11600 precipitation stations gridded on a $2.54^{\circ} \times 3.75^{\circ}$ grid from 1901 to 2010 (Donat et al., 2013). Here, gridded HadEX2 annual maximum 1day precipitation data (Rx1day) are analyzed as the observation data set. The Rx1day extreme precipitation index is defined as the annual-maximum daily precipitation, in which the maximum 1-day precipitation amount is selected for each year. The same index is also obtained for the climate model simulations. Daily precipitation amounts from simulations with 15 models (overall 19 runs) with complete temporal data coverage have been retrieved from the fifth phase of the Coupled Model Intercomparison Project (CMIP5) (Taylor et al., 2012), as the largest and most recent set of global climate model (GCM) runs. The historical data for projections from 1901 to 2005 and the high radiative forcing path scenario (representative concentration pathway, RCP) RCP8.5 (Moss et al., 2010) for projections from 2006 to 2010 are selected. The aforementioned 15 CMIP5 models, provided by the IRI/LDEO Climate Data Library, are BCC-CSM11, CMCC-CM, CMCC-CMS, CNRM-CM5, GFDL-CM3, GFDL-ESM2G, HadGEM2-CC, IPSL-CM5A-LR, IPSLCM5A-MR, IPSL-CM5B-LR, MIROC5 (three runs), MPIESM-LR (three runs), MPI-ESM-MR, MRI-CGCM3 and NorESM1-M.

Climate models produce simulated precipitation fields for all years of a specified time interval, covering all coordinates of the globe thoroughly, even the oceans and polar zones. This is completely different from the spatial and temporal coverage of station observation data sets, such as HadEX2, where usually cover only a certain part of the continents, with missing data for a considerable number of years. This differ- 

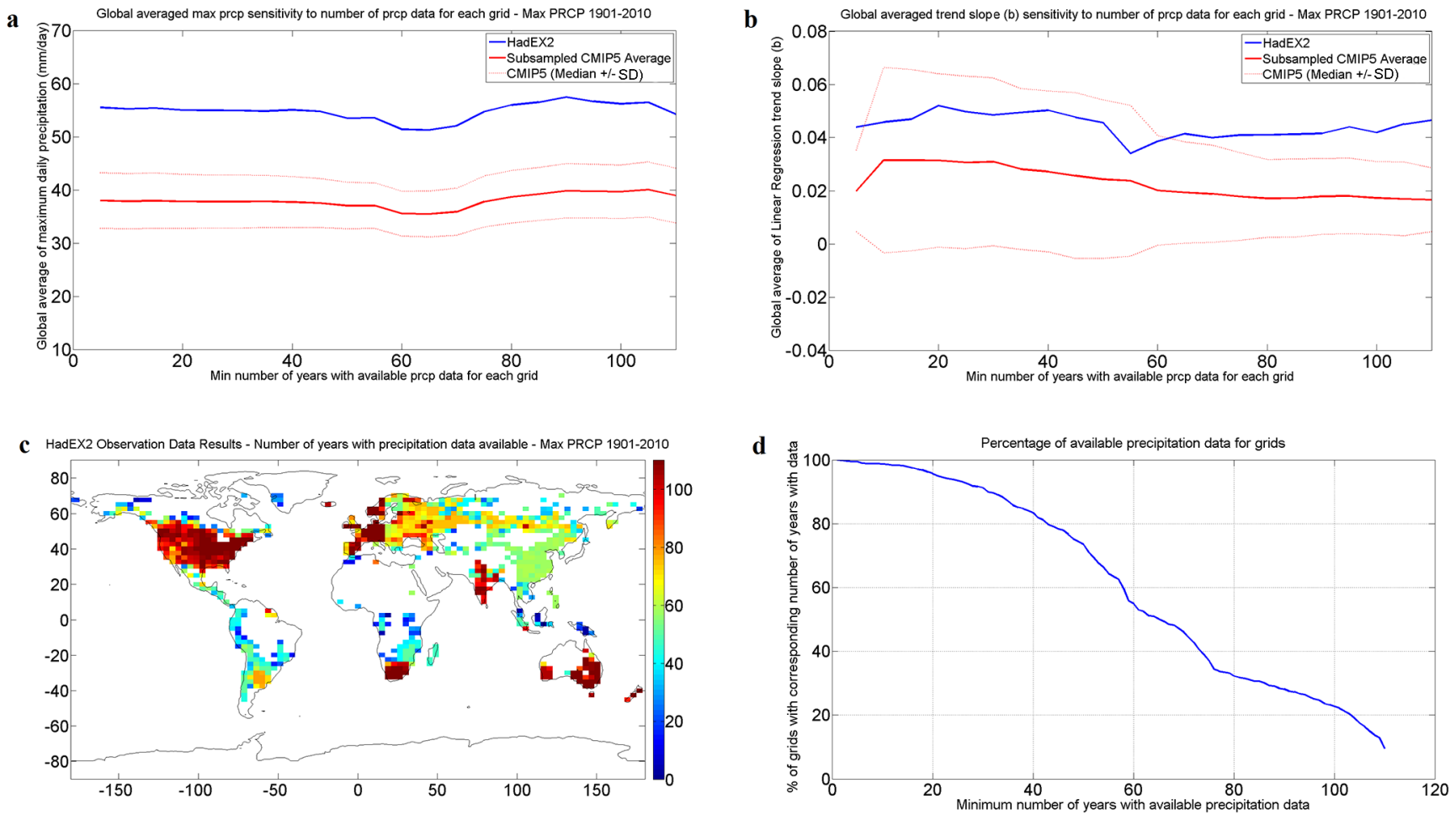

Figure 1. (a) Global averaged extreme precipitation and (b) linear regression trend slope averaged over HadEX2 grid cells with a different minimum number of years with extreme precipitation data available. (c) Map of the number of annual extreme precipitation records in HadEX2 (1901-2010). (d) Minimum number of years with extreme precipitation data available versus the percentage of the grid cells with corresponding coverage.

ence in coverage results in some difficulties in comparison of the two data sets.

As a solution for this issue, a new subsampled data set is created for each of the 19 CMIP5 climate models in which each of the HadEX2 grid cells take the GCM precipitation data of the grid cell in which its geo-referenced coordinates fit. The new data set is created with the same resolution and the same data availability pattern of HadEX2, which means that only data of the grids/years will be assigned to the new data set for which HadEX2 has recorded precipitation data for that year for the corresponding grid cell. The newly created data set is called the subsampled CMIP5 data set.

As stated above, most grid cells in HadEX2 do not have recorded precipitation data for most of the years. A sensitivity analysis of global averaged maximum precipitation and trend slopes to the minimum number of years with precipitation data required for a grid cell to be considered shows that these values do not change drastically (Fig. 1a and b). Selection of only stations with longer records may strengthen the confidence with which trends are quantified, but limits the calculations to smaller spatial coverage of the globe, which is not in line with the scope of this study to evaluate global changes in precipitation. We chose to use the grid cells with at least 30 years of available precipitation data over the last 110 years, which includes more than $90 \%$ of the
766 HadEX2 grid cells that had any Rx1day data (Fig. 1c and d).

Tests for trend detection in time series can be classified as parametric and non-parametric methods. Parametric trend tests require independence and a particular distribution in the data, while non-parametric trend tests require only that the data be independent. The trend slope $(b)$ obtained from the linear regression method, which assumes that the data variability follows a normal distribution, is utilized for trend strength analysis and comparison of the data sets. The relative change in extreme precipitation is defined as the trend slope divided by the average extreme precipitation of the grid cell $(b / P)$. The relative change in extreme precipitation per $\mathrm{K}$ of warming is also calculated as an index for the relation between changes in precipitation extremes of each grid cell with global mean near-surface temperature, which indicates the percentage change in extreme precipitation per $\mathrm{K}$ global warming. Linear regression is utilized to calculate this parameter, in which global annual mean near-surface temperature obtained from NASA-GISS (Hansen et al., 2010) is selected as the predictor and the natural logarithm of extreme precipitation time series is chosen as the response.

The $Z$ score $(Z)$ obtained from the Mann-Kendall test (Kendall, 1975; Mann, 1945) and the $Q$ median $\left(Q_{\text {med }}\right)$ from Sen's slope estimator (Sen, 1968) are also applied in order to 
Table 1. Statistics of variation of global average extreme precipitation for HadEX2 and the 19 subsampled CMIP5 model runs from 1901 to 2010 . The 19 climate model runs give 19 global averages, of which the minimum, maximum, median, mean, and standard deviation are presented.

\begin{tabular}{|c|c|c|c|c|c|c|c|}
\hline & & $\begin{array}{c}Q_{\text {med }} \\
\left(\mathrm{mm} \mathrm{day}^{-1} \mathrm{yr}^{-1}\right)\end{array}$ & $\begin{array}{c}Z \text { score } \\
(-)\end{array}$ & $\begin{array}{c}\text { Slope of } \\
\text { change }(b) \\
\left(\mathrm{mm} \mathrm{day}^{-1} \mathrm{yr}^{-1}\right)\end{array}$ & $\begin{array}{c}\text { Average of } \\
\text { extreme } \\
\text { precipitation } \\
(P)\left(\text { mm day }^{-1}\right)\end{array}$ & $\begin{array}{l}\text { Relative } \\
\text { change } \\
(b / P) \\
\left(\% \mathrm{yr}^{-1}\right)\end{array}$ & $\begin{array}{l}\text { Change per } \\
\text { degree } \\
\text { warming } \\
\left(\% \mathrm{~K}^{-1}\right)\end{array}$ \\
\hline \multirow{5}{*}{$\begin{array}{l}\text { CMIP5 } \\
\text { (subsampled) }\end{array}$} & $\begin{array}{l}\text { Model } \\
\text { min. }\end{array}$ & 0.0005 & 0.0944 & 0.0023 & 29.31 & 0.0118 & 4.37 \\
\hline & $\begin{array}{l}\text { Model } \\
\text { max. }\end{array}$ & 0.0648 & 0.7050 & 0.1592 & 48.46 & 0.3849 & 28.67 \\
\hline & $\begin{array}{l}\text { Model } \\
\text { median }\end{array}$ & 0.0218 & 0.3056 & 0.0271 & 37.89 & 0.0606 & 7.30 \\
\hline & $\begin{array}{l}\text { Model } \\
\text { SD }\end{array}$ & 0.0133 & 0.1555 & 0.0326 & 5.08 & 0.0774 & 5.16 \\
\hline & $\begin{array}{l}\text { Model } \\
\text { average }\end{array}$ & 0.0230 & 0.3330 & 0.0314 & 37.85 & 0.0797 & 8.43 \\
\hline HadEX2 & - & 0.0504 & 0.7242 & 0.0521 & 55.03 & 0.0775 & 9.99 \\
\hline
\end{tabular}

support the results of linear regression using non-parametric trend detection approaches. It is important to compare the non-parametric trend estimates with those obtained from linear regression, since the extreme precipitation time series need not follow the normal distribution but may instead be better represented by, for example, the generalized extreme value distribution (Katz, 1999; Westra et al., 2013). The trend tests are applied for each grid cell's extreme precipitation time series. The obtained values are averaged globally as well as by continent in order to present the general trend of precipitation extremes in different regions. Continents studied comprise Africa, Asia, Europe, North America, South America and Oceania. The subcontinent of India has results shown separately and is also included in Asia. Results are also averaged by latitude to investigate changes in the tropics versus the northern/southern mid-latitudes.

The statistical significance of the trends, presented in the text as well as the figures, at the $95 \%$ confidence level is based on $p$ values less than 0.05 from the linear regression. The statistical significance of trends estimated from the Mann-Kendall and Sen methods is evaluated differently (Appendix A).

\section{Results}

Linear regression indicates that $66.2 \%$ of the studied grid cells show a positive trend in annual-maximum daily precipitation during the past 110 years, including $18 \%$ that are statistically significant at the $95 \%$ confidence level. On the other hand, $33.8 \%$ of the studied grids show a negative trend, including only $4 \%$ that are statistically significant at the $95 \%$ confidence level. The results are very similar to those found by Westra et al. (2013) for the same HadEX2 data set (64\% positive and $36 \%$ negative). Thus, the global record of extreme precipitation shows a meaningful increase over the last century. This increase is expected to continue over the next decades, based on physical arguments and modeling (Kharin et al., 2007, 2013; O'Gorman and Schneider, 2009; Pall et al., 2006; Toreti et al., 2013).

Table 1 presents the statistics of global averaged trend parameters of annual-maximum daily precipitation for HadEX2 and 19 subsampled CMIP5 model runs (from 15 models) from 1901 to 2010 . Observation is only one data set; hence, it has one global average for each parameter. The 19 climate model runs give 19 global averages, of which we present the minimum, maximum, median, mean, and standard deviation in Table 1. Figure 2 illustrates the results presented in Table 1 as boxplots of trend parameters and average precipitation for annual-maximum daily precipitation for all 19 subsampled data sets of CMIP5 on global as well as continental scales, showing observations (HadEX2) as blue circles. The boxplots show the minimum, 25th percentile, median, 75th percentile and maximum values obtained from the climate models. As seen in Fig. 2a., the global average of extreme precipitation data shows a higher value than the largest value obtained from the climate models, which indicates that all of the climate models underestimate the annual-maximum daily precipitation. This underestimation can be seen in continental scale averages as well, and is expected given the difference in spatial scale between GCMs and station precipitation gauges.

The mean linear regression slope $(b)$ for HadEX2 observation data globally shows a positive trend of $0.052 \mathrm{~mm} \mathrm{day}^{-1}$ per year in extreme precipitation over the last 110 years (Table 1). This positive trend is captured by the climate models but is significantly underestimated, since HadEX2 shows a 
a

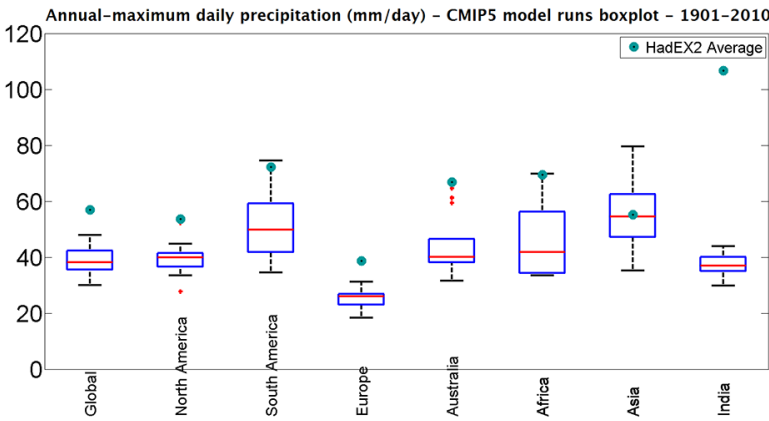

c

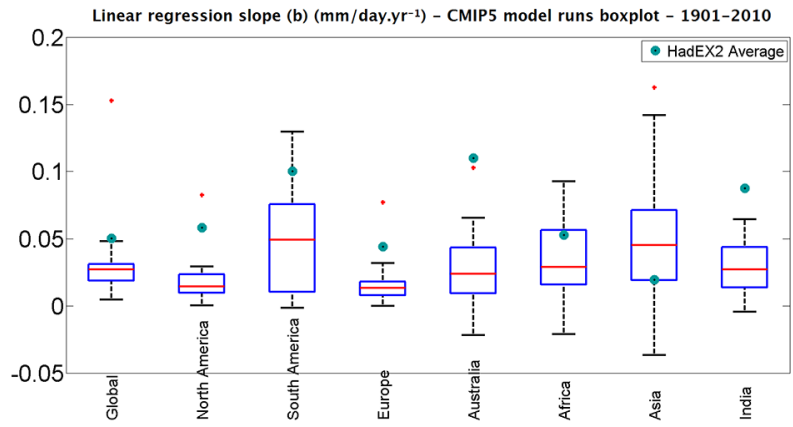

b

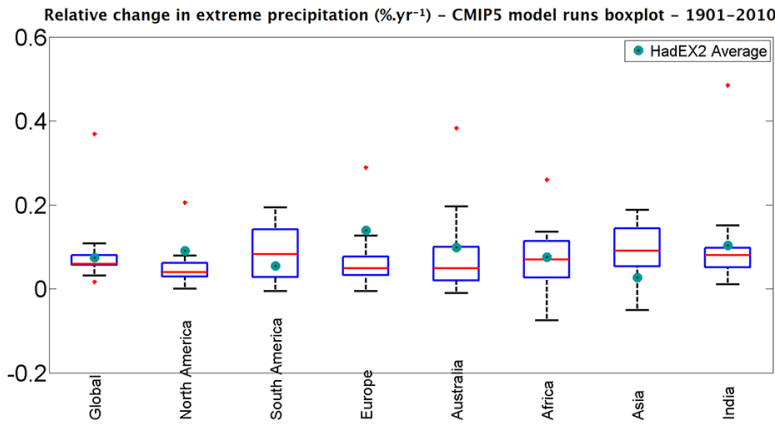

d

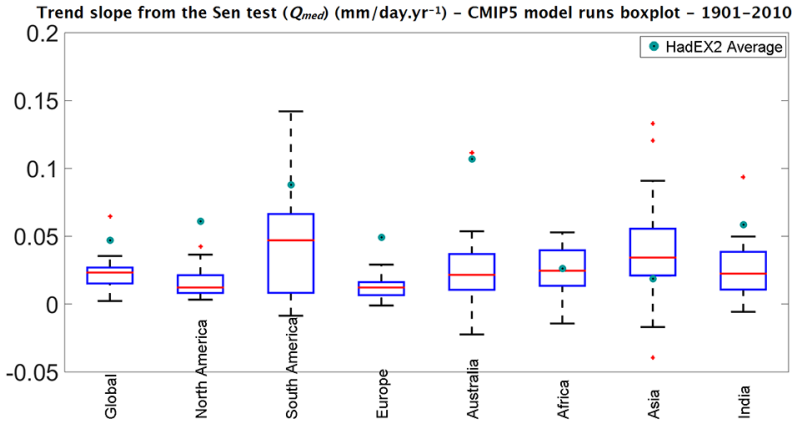

Figure 2. Boxplots of CMIP5 model run averaged results (minimum, 25th percentile, median, 75th percentile and maximum of the 19 model runs) as well as the average of HadEX2 observational data (shown as blue circles) for 1901-2010 extreme precipitation data on global and continental scales - (a) annual-maximum daily precipitation $\left(\mathrm{mm} \mathrm{day}^{-1}\right)$, (b) relative change in annual-maximum daily precipitation $\left(\% \mathrm{yr}^{-1}\right)$, (c) linear regression slope of change in annual-maximum extreme precipitation $\left(\mathrm{mm} \mathrm{day}^{-1} \mathrm{yr}^{-1}\right)$, and (d) trend slope from the Sen test $\left(Q_{\text {med }}\right)\left(\mathrm{mm} \mathrm{day}^{-1} \mathrm{yr}^{-1}\right)$. The red markers outside the boxes represent model outliers.

greater mean value of $b$ than all but one of the values obtained from CMIP5 models. This underestimation is seen particularly in the continents of America, Europe and Oceania as well as the subcontinent of India. The global average of relative change in precipitation $(b / P)$ for HadEX2 is close to the 75th percentile of the GCMs, which indicates that approximately $75 \%$ of the CMIP5 models have underestimated the relative change in extreme precipitation, but is close to the average value of the CMIP5 models. This substantial difference between the CMIP5 average and median value can be linked to the large and positive skew scatter among the results obtained from the models and the large inter-model standard deviation (Table 1). The observational relative changes in extreme precipitation for North America and Europe are higher than the values obtained from any of the CMIP5 climate models but, for South America, Oceania, Asia and Africa, are lower than the median of the CMIP5 models, suggesting that there may be coherent spatial patterns in the model bias (Fig. 2) analogous to those seen for changes in mean precipitation (Krakauer and Fekete, 2014).

Similar to the linear regression slope $(b), Q_{\text {med }}$ from Sen's test shows the direction and magnitude of the trend in a time series, having the advantage of using a non-parametric method for the trend test. The global average of $Q_{\text {med }}$ for observations is $0.050 \mathrm{~mm} \mathrm{day}^{-1}$ per year (Table 1 ), very close to the average value of $b$ obtained from the linear regression, which further supports increasing trends in observational annual-maximum daily precipitation. Considering the similar trend magnitudes from parametric and non-parametric methods, similar values for the relative change in annualmaximum daily precipitation are also expected from the two methods. As seen in Fig. 2, the boxplots of the distribution of $b$ and $Q_{\text {med }}$ over the climate models show very similar results on global and continental scales (Fig. $2 \mathrm{c}$ and d, respectively).

The last column of Table 1 presents a relative change in extreme precipitation per $\mathrm{K}$ of global warming $\left(\% \mathrm{~K}^{-1}\right)$. On a global scale, the observed annual-maximum daily precipitation has increased by an average of $10 \% \mathrm{~K}^{-1}$ of global warming since 1901 , which is larger than the average of climate models, with $8.3 \% \mathrm{~K}^{-1}$. The Clausius-Clapeyron equation under stable relative humidity indicates that atmospheric water vapor content will increase at a rate of approximately $7 \% \mathrm{~K}^{-1}$ warming (Held and Soden, 2006; Pall et al., 2006). The rates of increase in extreme precipitation per $K$ warming in both models and observations are higher than the rate of increase in atmospheric water vapor content per $\mathrm{K}$ warming expected from the Clausius-Clapeyron equation. Observational relative change in extreme precipitation with respect to global warming is also higher than all of the modeled values for North America and Europe, and is higher than the model median for South America, Africa and India, but 
$\mathbf{a}$

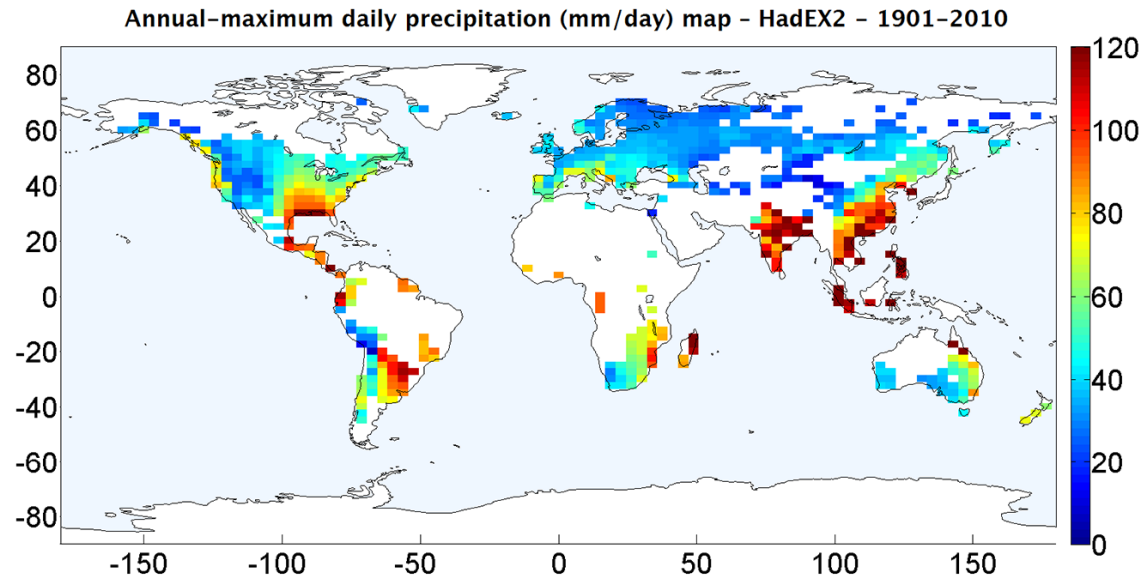

b

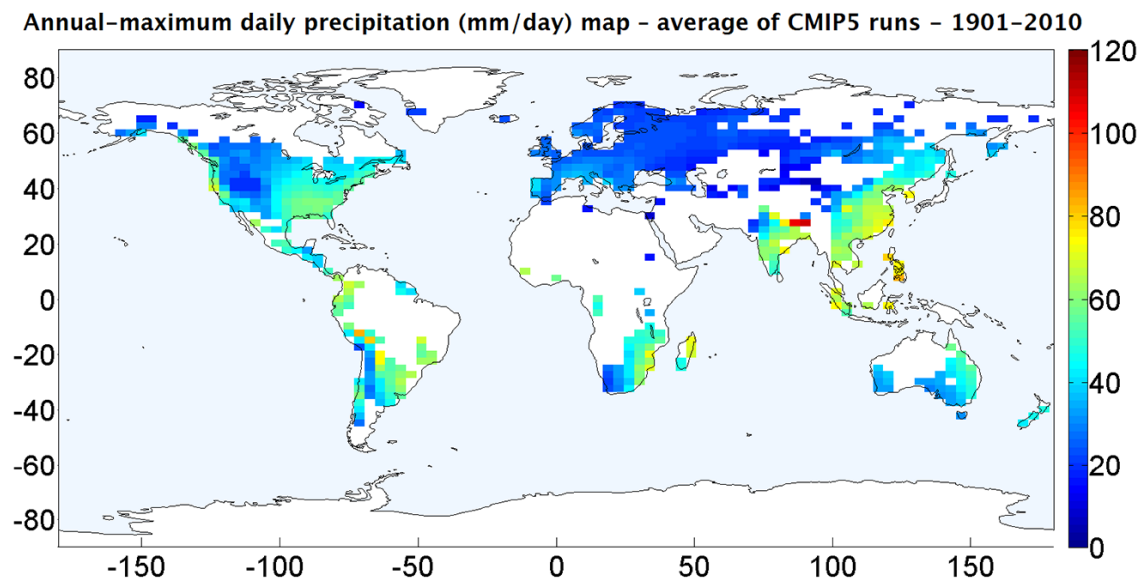

Figure 3. HadEX2 observational data versus CMIP5 averaged results of global extreme precipitation in 1901-2010 - annual-maximum daily precipitation map $\left(\mathrm{mm} \mathrm{day}^{-1}\right)$ for (a) HadEX2 and (b) the average of CMIP5 model runs.

is lower than the median of the models for Asia and Oceania (Fig. 8a).

Values of the $Z$ score index obtained from the MannKendall method shows the non-parametric confidence level of statistical significance in the identified trends in the data. The expectation might be that observational data would have a lower confidence level in the identified trends due to higher levels of noise in observations compared to climate model simulations. However, Table 1 shows that the global average value of the $Z$ score for HadEX2 is higher than the largest value obtained from the climate models, indicating that the CMIP5 climate models' simulations generally show lower level of confidence in the trends compared to the HadEX2 observations. This interesting finding that the level of internal variability in climate models appears to be too high compared to observations warrants further investigation.

Figure 3 depicts the global maps of the average of annualmaximum daily precipitation $(P)$ for HadEX2 (Fig. 3a) as well as the average of CMIP5 model runs (Fig. 3b). Figure 4 shows the linear regression slope (b) for HadEX2 (Fig. 4a) and the average of CMIP5 model runs (Fig. 4b). Relative change in extreme precipitation $(b / P)$ for HadEX2 as well as the average of CMIP5 model runs are illustrated in Fig. 5a and b, respectively. Stippling in Figs. 4 and 5 means that the grid cell has a significant trend at the $95 \%$ confidence level. In cases of CMIP5 average maps, filled/empty stippling indicates a positive/negative trend on average. While a larger marker size means a larger number of models agreeing on the presented trend, the largest marker size shown indicates only 7 out of 19 model simulations agreeing on the presented trend significance, which also illustrates the discrepancy in the trend significance between the climate models.

Figure 6 shows the average values of extreme precipitation $(P)$, linear regression trend slope $(b)$ and relative change in extreme precipitation $(b / P)$ at each $2.5^{\circ}$ latitudinal window (Fig. 6a-c). The figure presents the result of the HadEX2 data set with the average result of CMIP5 data sets as well as their mean \pm SD. As seen in Fig. 6a, average extreme precip- 
$\mathbf{a}$

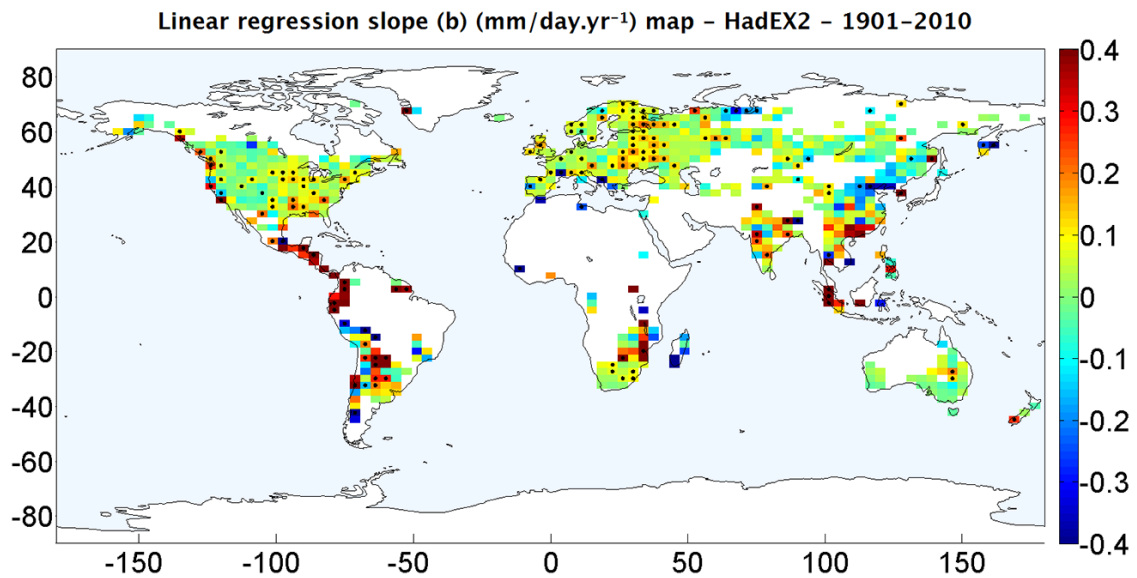

b

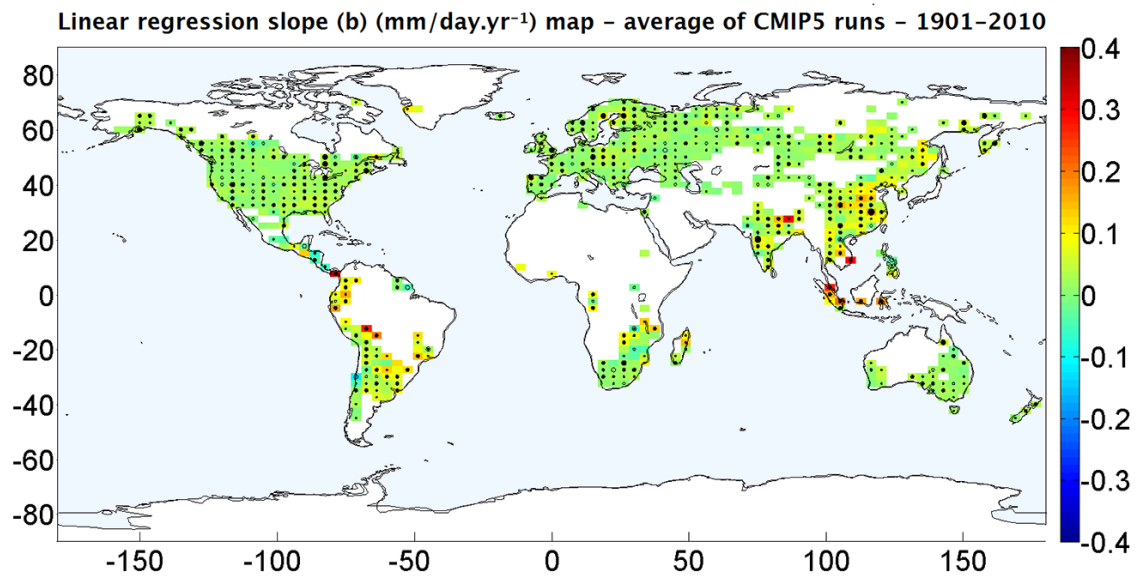

Figure 4. HadEX2 observational data versus CMIP5 averaged results of global extreme precipitation in 1901-2010 - linear regression slope of change in annual-maximum daily precipitation map $\left(\mathrm{mm} \mathrm{day}^{-1} \mathrm{yr}^{-1}\right)$ for (a) HadEX2 and (b) the average of CMIP5 model runs. Stippling indicates significance of the calculated trend at the $95 \%$ confidence level. In cases of CMIP5 average maps, filled/empty stippling indicates a positive/negative trend on average. The larger marker size means a larger number of models agreeing on the presented trend, with the largest one indicating only 7 out of 19 model runs agreeing on the presented trend significance, which also implies the discrepancy in the trend significance between the climate models.

itation observed and simulated in the Northern Hemisphere $(\mathrm{NH})$ is lower than in the Southern Hemisphere (SH), and the underestimation of extreme precipitation by the climate models can also be seen. Figure $6 \mathrm{~b}$ and $\mathrm{c}$ depict the fact that the SH shows larger percentage changes in extreme precipitation than the NH. Tropical zones of the globe show much higher ranges of fluctuations in both observed and simulated extreme precipitation trends compared to mid-latitudes, as well as a larger discrepancy between the observations and simulations (Fig. 6). There is larger uncertainty regarding the results in the tropics, due to fewer numbers of cells with observational data in these regions. The failure of climate models to capture changes in tropical zones has been reported by previous studies as well (Kharin et al., 2007; O'Gorman and Schneider, 2009).
Figure 7 depicts the relative change in extreme precipitation per K of global warming maps for HadEX2 observations (Fig. 7a) and the grid average of CMIP5 model runs (Fig. 7b). Boxplots of CMIP5 model run results as well as HadEX2 observational data (shown as blue circles) for relative change in extreme precipitation per $\mathrm{K}$ of global warming on global and continental scales are shown in Fig. 8a. Figure $8 \mathrm{~b}$ shows the relative change in extreme precipitation per $\mathrm{K}$ of global warming at each $2.5^{\circ}$ latitudinal window. As seen in Fig. 8b, the Southern Hemisphere shows higher ranges of relative changes in extreme precipitation per $\mathrm{K}$ global warming than the Northern Hemisphere. Similar behavior in fluctuations in observational extreme precipitation per $\mathrm{K}$ warming can also be seen in Westra et al. (2013) in the HadEX2 data set for 1900-2009, although the aforementioned study 
$\mathbf{a}$

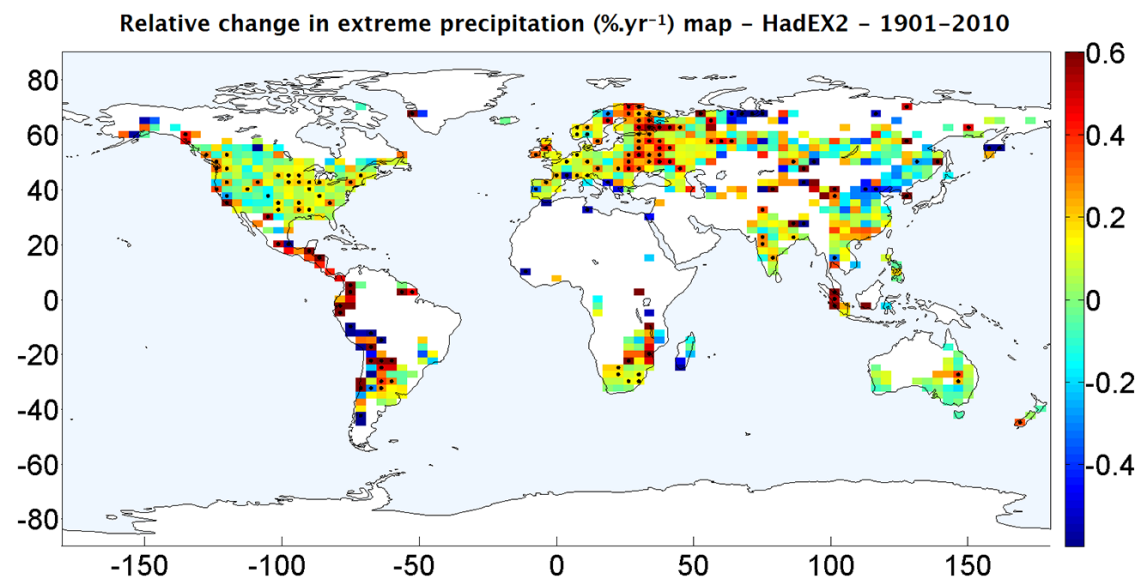

b

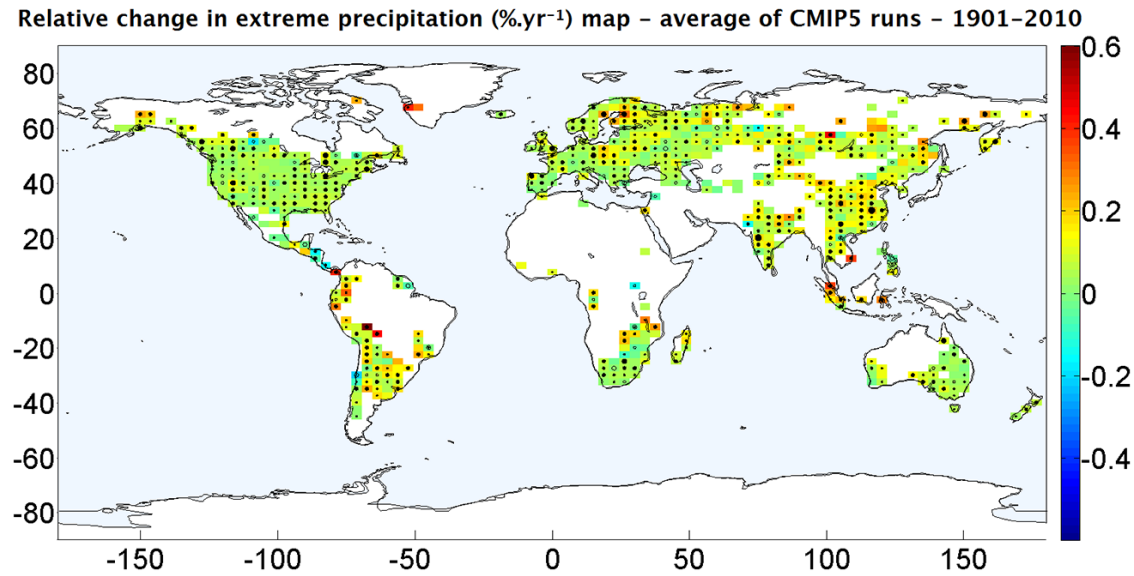

Figure 5. HadEX2 observational data versus CMIP5 averaged results of global extreme precipitation in 1901-2010 - relative change in annual-maximum daily precipitation ( $\left.\% \mathrm{yr}^{-1}\right)$ map for (a) HadEX2 and (b) the average of CMIP5 model runs. Stippling indicates significance of the calculated trend at the $95 \%$ confidence level. In cases of CMIP5 average maps, filled/empty stippling indicates a positive/negative trend on average. The larger marker size means a larger number of models agreeing on the presented trend, with the largest one indicating only 7 out of 19 model runs agreeing on the presented trend significance.

presents the results as the median of the trends across grid cells instead of the average.

\section{Discussion}

Results show that both observations and climate models show generally increasing trends in extreme precipitation intensity since 1901. Although the climate models reproduce the direction of observational trends on global and continental scales, the rate of change seems to be underestimated in most models, though the observations fall within the range of inter-model variability for at least the global mean relative change $(b / P)$. Similar discrepancies between observations and climate models have also been reported in earlier studies (Allan and Soden, 2008; Allen and Ingram, 2002; Min et al.,
2011; O'Gorman and Schneider, 2009; Sillmann et al., 2013; Wan et al., 2013; Wentz et al., 2007; Zhang et al., 2007).

The global average of trends from the non-parametric method ( $Q_{\text {med }}$ from Sen's slope estimator) show similar values to those obtained from the parametric method ( $b$ from the linear regression) in observations, confirming the results of the parametric method, which further supports an increasing trend in observational annual-maximum daily precipitation (Table 1 and Fig. 2c and d). Also, the boxplots of $b$ and $Q_{\text {med }}$ for climate models are very similar on global and continental scales for different percentiles (Fig. 2c and d, respectively).

Tropical latitudes show higher ranges of fluctuations observed and simulated for extreme precipitation trends compared to mid-latitudes, as well as a larger discrepancy between the observations and simulations (Fig. 6). The high variation of the results for observations as well as models might be due to the small number of data available for those 
a

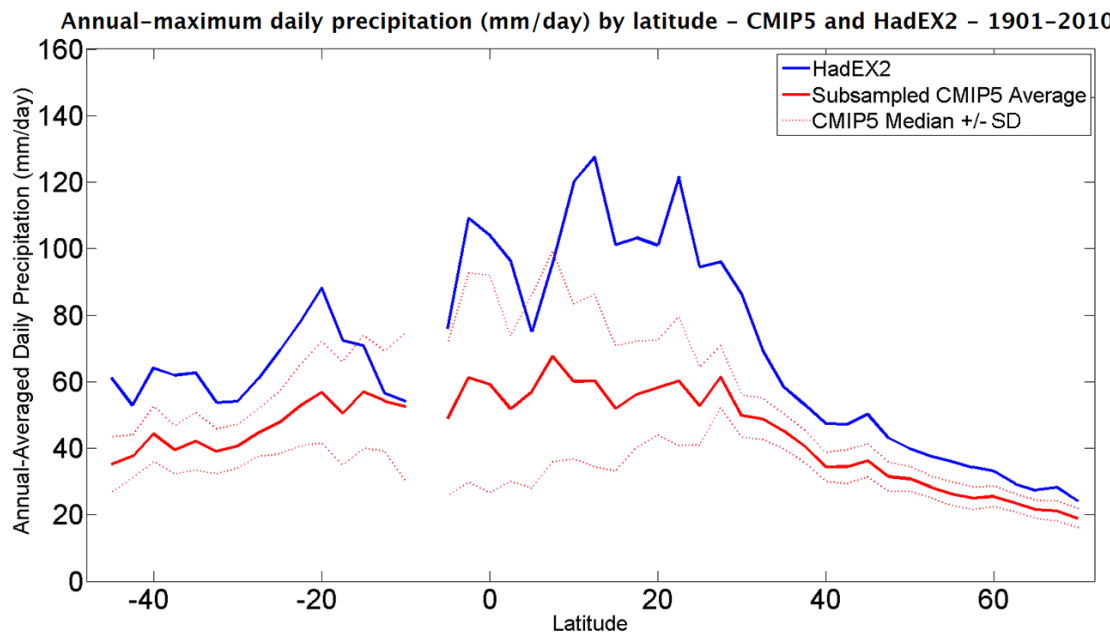

b

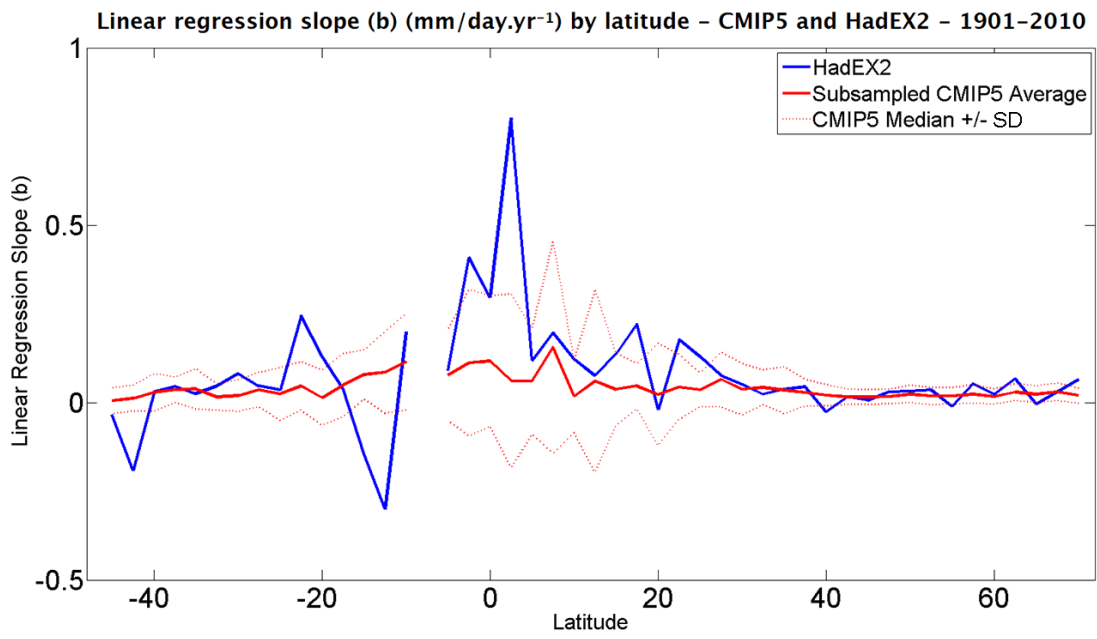

c

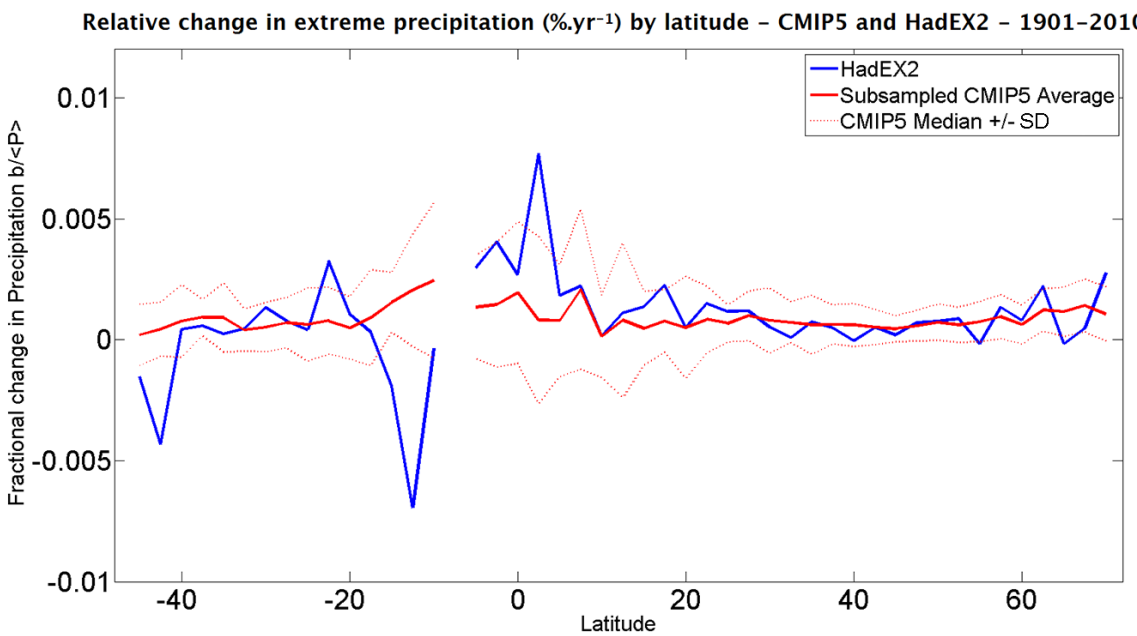

Figure 6. Average parameter value at each $2.5^{\circ}$ latitudinal window - (a) annual-maximum daily precipitation $\left(\mathrm{mm}^{-1 a y}{ }^{-1}\right)$ for HadEX2 and average CMIP5, (b) slope of change in annual-maximum daily extreme precipitation (mm day ${ }^{-1} \mathrm{yr}^{-1}$ ) for HadEX2 and average CMIP5, and (c) relative change in extreme precipitation $\left(\% \mathrm{yr}^{-1}\right)$ for HadEX2 and average CMIP5. Values for the climate models are averages of the 19 runs and the dashed lines are the medians of the models plus/minus the standard deviation of the models. The gap in the tropics indicates the lack of grid cells with more than 30 years of precipitation data available in those zones. 
$\mathbf{a}$

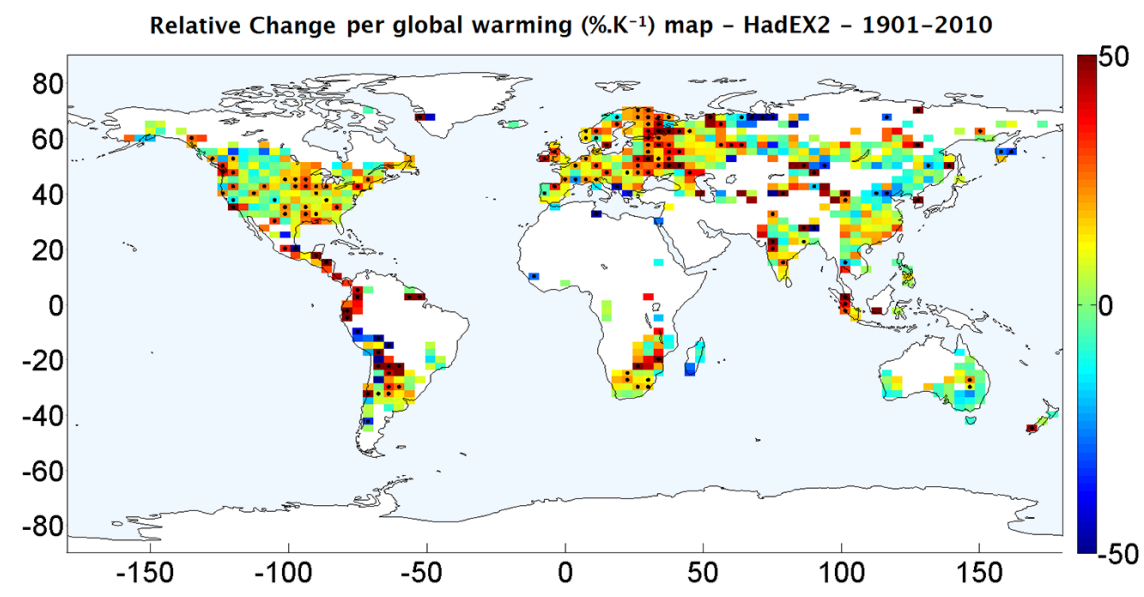

b

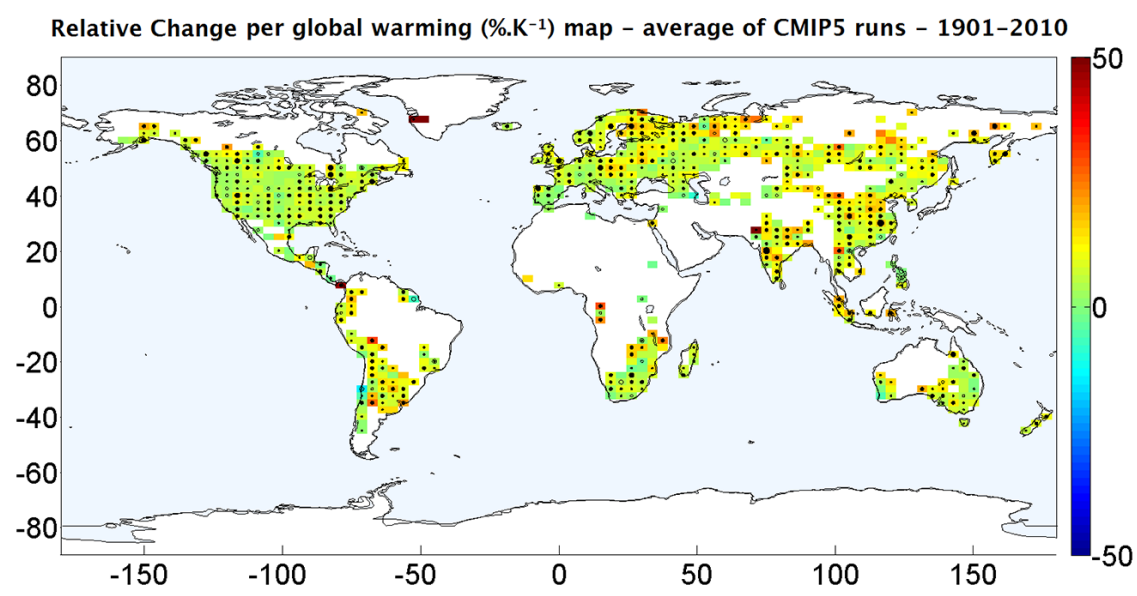

Figure 7. Relative change in extreme precipitation per $\mathrm{K}$ of global warming (\% $\mathrm{K}^{-1}$ ) maps for 1901-2010 for (a) HadEX2 observations and (b) the average of CMIP5 model runs.

regions, given that the models are sub-sampled the same way as the available observations. However, the larger discrepancy between observations and models in tropics might also be a result of inaccuracy of the climate models in simulation of tropical climate and of precipitation generated by deep convection, as reported by previous studies (O'Gorman and Schneider, 2009). The continents of North America, Europe and Asia, respectively, contain about 22,18 and $34 \%$ of total global data grid cells (Fig. 1c). The trend results averaged for the continents of North America and Europe are generally in line with global averaged results. The subcontinent of India generally shows different results from the Asia average, in both observations and models (Figs. 2 and 8a).

The Clausius-Clapeyron equation indicates that atmospheric water vapor content increases at a rate of $7 \% \mathrm{~K}^{-1}$ of warming (Held and Soden, 2006; Pall et al., 2006). Although a change in global-mean precipitation with respect to warming does not scale with the Clausius-Clapeyron equation and from energy balance consideration, the rate of increase might be expected to be around $2 \% \mathrm{~K}^{-1}$ (Held and Soden, 2006). The impact of global warming on extreme precipitation is expected to be close to the Clausius-Clapeyron slope (Pall et al., 2006). The results of the present study show that, on average, extreme precipitation since 1901 has increased by $10 \% \mathrm{~K}^{-1}$ of global warming in observations and $8.3 \% \mathrm{~K}^{-1}$ in climate models over land areas with available station observations (Table 1). North and South America as well as Europe show an even stronger increase in extreme precipitation with respect to global warming (Fig. 8a). These numbers are considerably larger than the $7 \% \mathrm{~K}^{-1}$ of the ClausiusClapeyron equation, which further emphasizes the impact of changes in the Earth's global temperature on precipitation extremes.

As stated earlier, increased availability of moisture in the atmosphere is expected to result in a greater increase in intensity of extreme precipitation than for mean precipitation (Lambert et al., 2008; Pall et al., 2006). Faster change in extreme precipitation than mean precipitation implies a change 
a

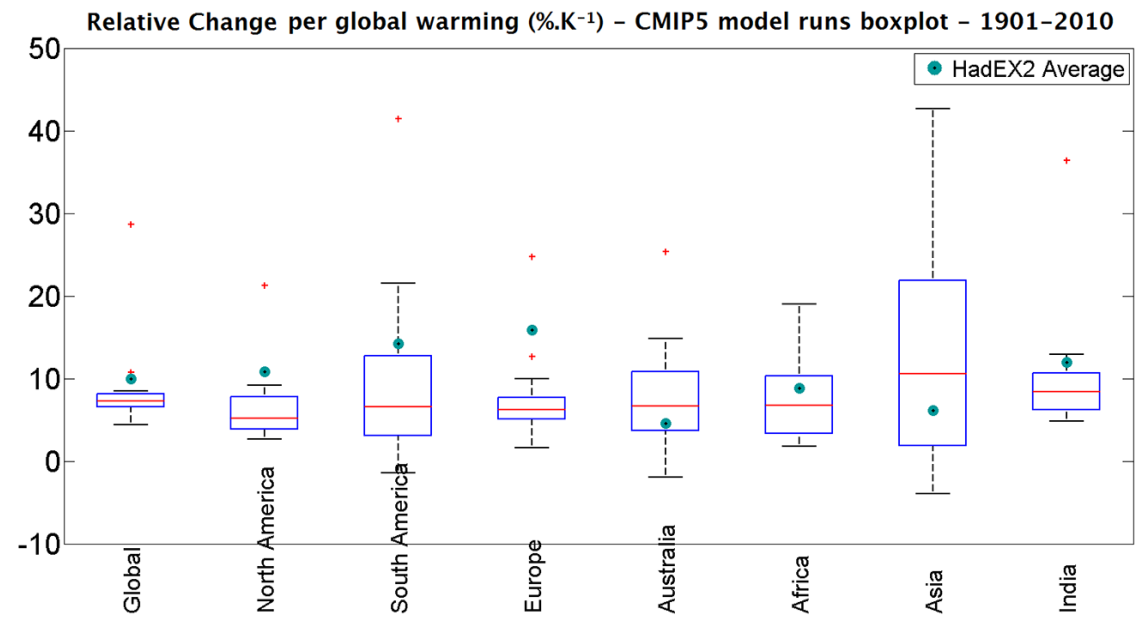

b

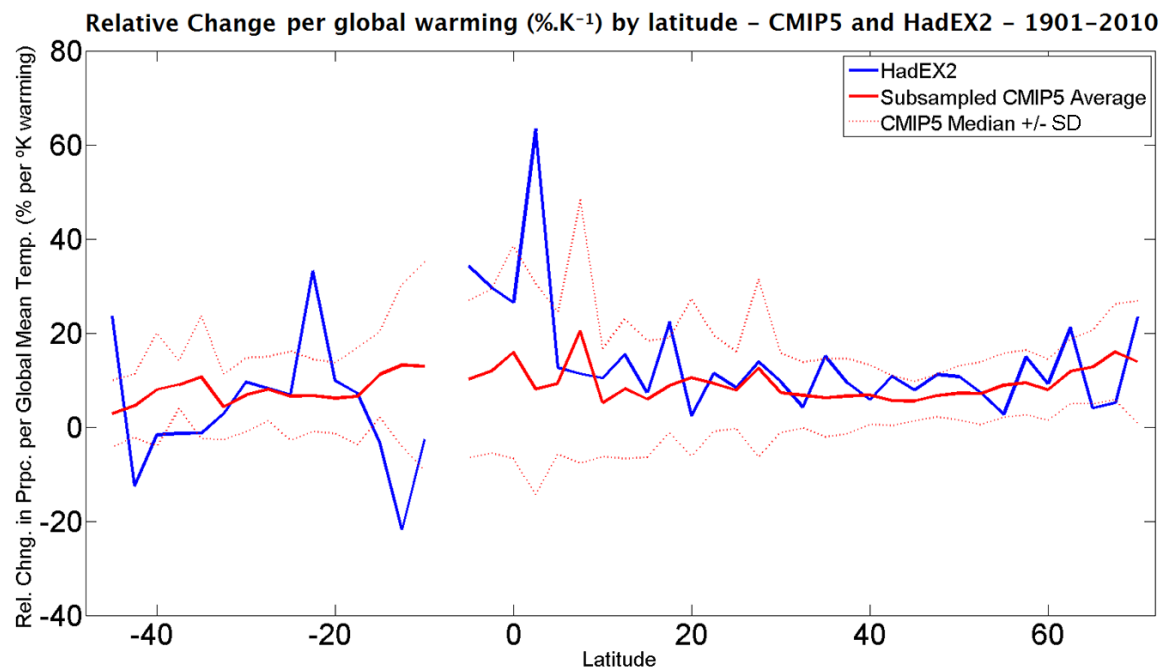

Figure 8. Relative change in extreme precipitation per K of global warming (\% $\mathrm{K}^{-1}$ ) in 1901-2010 - (a) boxplots of CMIP5 model run averaged results (minimum, 25th percentile, median, 75th percentile and maximum of the 19 model runs) as well as the average of HadEX2 observational data (shown as blue circles) on global and continental scales and (b) average changes at each $2.5^{\circ}$ latitudinal window.

in precipitation pattern, where the climate shifts to fewer rainy days and more intense precipitation. This can affect the availability of fresh water resources throughout the year. Such changes in precipitation pattern can affect the capability of reservoirs to capture excessive surface run-off and result in increased flooding events. Failure of the available reservoirs to capture the designed amount of annual surface run-off might also result in a lower total annual amount of water stored in the reservoir, and hence fewer available fresh water resources. The design of newly constructed reservoirs strongly depends on the appropriate prediction of future climate and precipitation extremes, but the available climate models seem to underestimate those for at least some regions. The consequences of changes in both mean and extreme precipitation for water resource system reliability deserve to be investigated further.

\section{Conclusions}

This study presented a systematic global-scale comparison of changes in historical annual-maximum daily precipitation between the HadEX2 observational records and a CMIP5 ensemble of global climate models. The climate models were spatially and temporally subsampled like the observations, and trends were analyzed for grid cells with at least 30 years of extreme precipitation data over the past 110 years. Both parametric and non-parametric methods were used to quantify the strength of trends in extreme precipitation as well as the confidence level of the identified trends. Results from both parametric and non-parametric tests show that both observations and climate models show generally increasing trends in extreme precipitation since 1901, with larger changes in tropical zones, although annual-maximum daily 
precipitation has increased faster in the observations than in most of the CMIP5 models. Observations indicate that approximately one-fifth of the global data-covered land area had significant increasing maximum precipitation recorded during the last century. This is more than 4 times larger than the areas with a significant decreasing record, which indicates that the global record of extreme precipitation shows a meaningful increase over the last century. On a global scale, the observational annual-maximum daily precipitation has increased by an average of $5.73 \mathrm{~mm} \mathrm{day}^{-1}$ over the last 110 years, or $8.53 \%$ in relative terms. The observational annual-maximum daily precipitation has also increased by an average of $10 \% \mathrm{~K}^{-1}$ of global warming since 1901, which is larger than the average of climate models, with $8.3 \% \mathrm{~K}^{-1}$. The rates of increase in extreme precipitation per $\mathrm{K}$ of warming in both models and observations are higher than the rate of increase in atmospheric water vapor content per $\mathrm{K}$ of warming expected from the Clausius-Clapeyron equation, which is approximately $7 \% \mathrm{~K}^{-1}$, which highlights the importance of extreme precipitation trends for water resource planning. 


\section{Appendix A: Non-parametric trend tests}

\section{A1 Mann-Kendall trend test}

The MK test is a non-parametric rank-based test (Kendall, 1975; Mann, 1945). The Mann-Kendall test statistic $S$ is calculated as

$S=\sum_{i=1}^{n-1} \sum_{j=i+1}^{n} \operatorname{sgn}\left(x_{j}-x_{i}\right)$,

where $n$ is the number of data points, $x_{i}$ and $x_{j}$ are the data values in time series $i$ and $j(j>i)$, respectively, and $\operatorname{sgn}\left(x_{j}-x_{i}\right)$ is the sign function

$\operatorname{sgn}\left(x_{j}-x_{i}\right)= \begin{cases}+1 & \text { if } x_{j}-x_{i}>0 \\ 0, & \text { if } x_{j}-x_{i}=0 \\ -1 & \text { if } x_{j}-x_{i}<0\end{cases}$

The variance is computed using the equation below:

$\operatorname{Var}(S)=\frac{n(n-1)(2 n+5)-\sum_{i=1}^{m} t_{i}\left(t_{i}-1\right)\left(2 t_{i}+5\right)}{18}$,

where $n$ is the number of data points, $m$ is the number of tied groups and $t_{i}$ is the number of ties of extent $i$. A tied group is a set of sample data having the same value. In cases where the sample size $n$ is greater than 10 , the standard normal test statistic $Z_{\mathrm{S}}$ is computed as

$Z_{\mathrm{S}}= \begin{cases}\frac{S-1}{\sqrt{\operatorname{Var}(S)}}, & \text { if } S>0 \\ 0, & \text { if } S=0 \\ \frac{S+1}{\sqrt{\operatorname{Var}(S)}}, & \text { if } S<0\end{cases}$

The sign of $Z_{\mathrm{S}}$ indicates the trend in the data series, where positive values of $Z_{\mathrm{S}}$ mean an increasing trend, while negative $Z_{\mathrm{S}}$ values show decreasing trends. For the tests at a specific $\alpha$ significance level, if $\left|Z_{S}\right|>Z_{1-\alpha / 2}$, the null hypothesis is rejected and the time series has a statistically significant trend.
$Z_{1-\alpha / 2}$ is obtained from the standard normal distribution table, where, at the $5 \%$ significance level $(\alpha=0.05)$, the trend is statistically significant if $\left|Z_{S}\right|>1.96$ and, at the $1 \%$ significance level $(\alpha=0.01)$, the trend is statistically significant if $\left|Z_{S}\right|>2.576$.

\section{A2 Sen's slope estimator}

The non-parametric procedure for estimating the slope of the trend in the sample of $N$ pairs of data was developed by Sen (1968) as

$Q_{i}=\frac{x_{j}-x_{k}}{j-k}$ for $i=1, \ldots, N$,

where $x_{j}$ and $x_{k}$ are the data values at times $j$ and $k(j>k)$, respectively. $N$ is defined as $\frac{n(n-1)}{2}$, where $n$ is the number of time periods.

If the $N$ values of $Q_{i}$ are ranked from smallest to largest, the parameter $Q_{\text {med }}$ is computed as the median of the $\boldsymbol{Q}_{i}$ vector. The $Q_{\text {med }}$ sign reflects the direction of trend, while its value indicates the magnitude of the trend. To determine whether the median slope is statistically different than zero, the confidence interval of $Q_{\text {med }}$ at a specific probability should be computed as follows (Gilbert, 1987; Hollander and Wolfe, 1973):

$C_{\alpha}=Z_{1-\alpha / 2} \sqrt{\operatorname{Var}(S)}$,

where $\operatorname{Var}(S)$ is defined before and $Z_{1-\alpha / 2}$ is obtained from the standard normal distribution table. Then, $M_{1}=\frac{N-C_{\alpha}}{2}$ and $M_{2}=\frac{N+C_{\alpha}}{2}$ are computed. The lower and upper limits of the confidence interval, $Q_{\min }$ and $Q_{\max }$, are the $M_{1}$ th largest and the $\left(M_{2}+1\right)$ th largest of the $N$ ordered slope estimates (Gilbert, 1987). The slope $Q_{\text {med }}$ is statistically different than zero if the two limits $Q_{\min }$ and $Q_{\max }$ have the same sign. 
Acknowledgements. The authors gratefully acknowledge support from NOAA under grants NA11SEC4810004 and NA12OAR4310084. All statements made are the views of the authors and not the opinions of the funding agency or the US government.

Edited by: P. Gentine

\section{References}

Alexander, L. V., Zhang, X., Peterson, T. C., Caesar, J., Gleason, B., Klein Tank, A. M. G., Haylock, M., Collins, D., Trewin, B., Rahimzadeh, F., Tagipour, A., Rupa Kumar, K., Revadekar, J., Griffiths, G., Vincent, L., Stephenson, D. B., Burn, J., Aguilar, E., Brunet, M., Taylor, M., New, M., Zhai, P., Rusticucci, M., and Vazquez-Aguirre, J. L.: Global observed changes in daily climate extremes of temperature and precipitation, J. Geophys. Res., 111, D05109, doi:10.1029/2005JD006290, 2006.

Allan, R. P. and Soden, B. J.: Atmospheric warming and the amplification of precipitation extremes, Science, 321, 1481-1484, doi:10.1126/science.1160787, 2008.

Allen, M. R. and Ingram, W. J.: Constraints on future changes in climate and the hydrologic cycle, Nature, 419, 224-232, doi:10.1038/nature01092, 2002.

Angeles, M. E., Gonzalez, J. E., Iii, J. E., Hern, L., National, R., and Ridge, O.: Predictions of future climate change in the Caribbean region using global general circulation models, Int. J. Climatol., 27, 555-569, doi:10.1002/joc.1416, 2007.

Campbell, J. D., Taylor, M. A., Stephenson, T. S., Watson, R. A., and Whyte, F. S.: Future climate of the Caribbean from a regional climate model, Int. J. Climatol., 31, 1866-1878, doi:10.1002/joc.2200, 2011.

Chen, C.-T. and Knutson, T.: On the Verification and Comparison of Extreme Rainfall Indices from Climate Models, J. Climate, 21, 1605-1621, doi:10.1175/2007JCLI1494.1, 2008.

Chou, C. and Neelin, J.: Mechanisms of global warming impacts on regional tropical precipitation, J. Climate, 17, 2688-2701, doi:10.1175/1520-0442(2004)017<2688:MOGWIO>2.0.CO;2, 2004.

Dankers, R., Arnell, N. W., Clark, D. B., Falloon, P. D., Fekete, B. M., Gosling, S. N., Heinke, J., Kim, H., Masaki, Y., Satoh, Y., Stacke, T., Wada, Y., and Wisser, D.: First look at changes in flood hazard in the Inter-Sectoral Impact Model Intercomparison Project ensemble, P. Natl. Acad. Sci. USA, 111, 3257-3261, doi:10.1073/pnas.1302078110, 2013.

Donat, M. G., Alexander, L. V., Yang, H., Durre, I., Vose, R., Dunn, R. J. H., Willett, K. M., Aguilar, E., Brunet, M., Caesar, J., Hewitson, B., Jack, C., Klein Tank, A. M. G., Kruger, A. C., Marengo, J., Peterson, T. C., Renom, M., Oria Rojas, C., Rusticucci, M., Salinger, J., Elrayah, A. S., Sekele, S. S., Srivastava, A. K., Trewin, B., Villarroel, C., Vincent, L. A., Zhai, P., Zhang, X., and Kitching, S.: Updated analyses of temperature and precipitation extreme indices since the beginning of the twentieth century: The HadEX2 dataset, J. Geophys. Res.-Atmos., 118, 2098-2118, doi:10.1002/jgrd.50150, 2013.

Easterling, D. R., Evans, J. L., Groisman, P. Y., Karl, T. R., Kunkel, K. E., and Ambenje, P.: Observed Variability and Trends in Extreme Climate Events: A Brief Re- view, B. Am. Meteorol. Soc., 81, 417-425, doi:10.1175/15200477(2000)081<0417:OVATIE>2.3.CO;2, 2000.

Field, C. B.: Managing the risks of extreme events and disasters to advance climate change adaptation: special report of the intergovernmental panel on climate change, Cambridge University Press, Cambridge, UK, 2012.

Gilbert, R. O.: Statistical Methods for Environmental Pollution Monitoring, John Wiley \& Sons, New York, USA, 1987.

Hansen, J., Ruedy, R., Sato, M., and Lo, K.: Global surface temperature change, Rev. Geophys., 48, RG4004, doi:10.1029/2010RG000345, 2010.

Held, I. M. and Soden, B. J.: Robust Responses of the Hydrological Cycle to Global Warming, J. Climate, 19, 5686-5699, doi:10.1175/JCLI3990.1, 2006.

Hollander, M. and Wolfe, D. A.: Nonparametric Statistical Methods, J. W. \& Sons, New York, USA, 1973.

Katz, R. W.: Extreme value theory for precipitation: sensitivity analysis for climate change, Adv. Water Resour., 23, 133-139, doi:10.1016/S0309-1708(99)00017-2, 1999.

Kendall, M. G.: Rank Correlation Methods, Charless Griffin, London, UK, 1975.

Kharin, V. V., Zwiers, F. W., Zhang, X., and Hegerl, G. C.: Changes in Temperature and Precipitation Extremes in the IPCC Ensemble of Global Coupled Model Simulations, J. Climate, 20, 14191444, doi:10.1175/JCLI4066.1, 2007.

Kharin, V. V., Zwiers, F. W., Zhang, X., and Wehner, M.: Changes in temperature and precipitation extremes in the CMIP5 ensemble, Climatic Change, 119, 345-357, doi:10.1007/s10584-013-07058, 2013.

Krakauer, N. Y. and Fekete, B. M.: Are climate model simulations useful for forecasting precipitation trends? Hindcast and synthetic-data experiments, Environ. Res. Lett., 9, 024009, doi:10.1088/1748-9326/9/2/024009, 2014.

Lambert, F. H., Stine, A. R., Krakauer, N. Y., and Chiang, J. C. H.: How Much Will Precipitation Increase With Global Warming?, Eos T. Am. Geophys. Un., 89, 193-194, doi:10.1029/2008EO210001, 2008.

Mann, H. B.: Nonparametric tests against trend, Econometrica, 13, 245-259, 1945.

Min, S.-K., Zhang, X., Zwiers, F. W., and Hegerl, G. C.: Human contribution to more-intense precipitation extremes, Nature, 470 , 378-81, doi:10.1038/nature09763, 2011.

Moss, R. H., Edmonds, J. A., Hibbard, K. A., Manning, M. R., Rose, S. K., van Vuuren, D. P., Carter, T. R., Emori, S., Kainuma, M., Kram, T., Meehl, G. A., Mitchell, J. F. B., Nakicenovic, N., Riahi, K., Smith, S. J., Stouffer, R. J., Thomson, A. M., Weyant, J. P., and Wilbanks, T. J.: The next generation of scenarios for climate change research and assessment, Nature, 463, 747-756, doi:10.1038/nature08823, 2010.

O'Gorman, P. A. and Schneider, T.: The physical basis for increases in precipitation extremes in simulations of 21stcentury climate change, P. Natl. Acad. Sci., 106, 14773-14777, doi:10.1073/pnas.0907610106, 2009.

Pall, P., Allen, M. R., and Stone, D. A.: Testing the ClausiusClapeyron constraint on changes in extreme precipitation under $\mathrm{CO}_{2}$ warming, Clim. Dyn., 28, 351-363, doi:10.1007/s00382006-0180-2, 2006. 
Peterson, T. C.: Recent changes in climate extremes in the Caribbean region, J. Geophys. Res., 107, 4601, doi:10.1029/2002JD002251, 2002.

Scoccimarro, E., Gualdi, S., Bellucci, A., Zampieri, M., and Navarra, A.: Heavy Precipitation Events in a Warmer Climate: Results from CMIP5 Models, J. Climate, 26, 7902-7911, doi:10.1175/JCLI-D-12-00850.1, 2013.

Sen, P. K.: Estimates of the regression coefficient based on Kendall's tau, J. Am. Stat. Assoc., 63, 1379-1389, doi:10.1080/01621459.1968.10480934, 1968.

Sillmann, J., Kharin, V. V., Zhang, X., Zwiers, F. W., and Bronaugh, D.: Climate extremes indices in the CMIP5 multimodel ensemble: Part 1. Model evaluation in the present climate, J. Geophys. Res.-Atmos., 118, 1716-1733, doi:10.1002/jgrd.50203, 2013.

Singh, B.: Climate-related global changes in the southern Caribbean: Trinidad and Tobago, Global Planet. Change, 15, 93111, doi:10.1016/S0921-8181(97)00006-4, 1997.

Solomon, S., Qin, D., Manning, M., Marquis, M., Averyt, K., Tignor, M. M. B., Miller, H. L., and Chen, Z.: Climate Change 2007: The Physical Science Basis, Contribution of Working Group I to the Fourth Assessment Report of the IPCC, Vol. 4, Cambridge University Press, 2007.

Stocker, T. F., Qin, D., Plattner, G.-K., Tignor, M. M. B., Allen, S. K., Boschung, J., Nauels, A., Xia, Y., and Bex, V.: Climate Change 2013: The Physical Science Basis. Working Group I Contribution to the Fifth Assessment Report of the Intergovernmental Panel on Climate Change-Abstract for decision-makers, C/O World Meteorological Organization, Geneva, Switzerland, 2013.

Taylor, K. E., Stouffer, R. J., and Meehl, G. A.: An Overview of CMIP5 and the Experiment Design, B. Am. Meteorol. Soc., 93, 485-498, doi:10.1175/BAMS-D-11-00094.1, 2012.

Taylor, M. A., Centella, A., Charlery, J., Borrajero, I., Bezanilla, A., Campbell, J., and Watson, R.: Glimpses of the future - a briefing from PRECIS Caribbean climate change project, Belmopan, Belize, 2007.

Toreti, A., Naveau, P., Zampieri, M., Schindler, A., Scoccimarro, E., Xoplaki, E., Dijkstra, H. A., Gualdi, S., and Luterbacher, J.: Projections of global changes in precipitation extremes from Coupled Model Intercomparison Project Phase 5 models, Geophys. Res. Lett., 40, 4887-4892, doi:10.1002/grl.50940, 2013.
Trenberth, K. E.: Conceptual Framework for Changes of Extremes of the Hydrological Cycle With Climate Change, Climatic Change, 42, 327-339, doi:10.1023/a:1005488920935, 1999.

Trenberth, K. E.: Changes in precipitation with climate change, Clim. Res., 47, 123-138, doi:10.3354/cr00953, 2011.

Trenberth, K. E., Dai, A., Rasmussen, R. M., and Parsons, D. B.: The Changing Character of Precipitation, B. Am. Meteorol. Soc., 84, 1205-1217, doi:10.1175/BAMS-84-9-1205, 2003.

Trenberth, K. E., Fasullo, J., and Smith, L.: Trends and variability in column-integrated atmospheric water vapor, Clim. Dynam., 24, 741-758, doi:10.1007/s00382-005-0017-4, 2005.

Wan, H., Zhang, X., Zwiers, F. W., and Shiogama, H.: Effect of data coverage on the estimation of mean and variability of precipitation at global and regional scales, J. Geophys. Res.-Atmos., 118, 534-546, doi:10.1002/jgrd.50118, 2013.

Wentz, F. J., Ricciardulli, L., Hilburn, K., and Mears, C.: How much more rain will global warming bring?, Science, 317, 233-235, doi:10.1126/science.1140746, 2007.

Westra, S., Alexander, L. V., and Zwiers, F. W.: Global Increasing Trends in Annual Maximum Daily Precipitation, J. Climate, 26, 3904-3918, doi:10.1175/JCLI-D-12-00502.1, 2013.

Wilcox, E. M. and Donner, L. J.: The Frequency of Extreme Rain Events in Satellite Rain-Rate Estimates and an Atmospheric General Circulation Model, J. Climate, 20, 53-69, doi:10.1175/JCLI3987.1, 2007.

Zhang, X., Zwiers, F. W., Hegerl, G. C., Lambert, F. H., Gillett, N. P., Solomon, S., Stott, P. A., and Nozawa, T.: Detection of human influence on twentieth-century precipitation trends, Nature, 448, 461-465, doi:10.1038/nature06025, 2007.

Zhang, X., Alexander, L., Hegerl, G. C., Jones, P., Tank, A. K., Peterson, T. C., Trewin, B., and Zwiers, F. W.: Indices for monitoring changes in extremes based on daily temperature and precipitation data, Wiley Interdiscip. Rev. Clim. Chang., 2, 851-870, doi:10.1002/wcc.147, 2011. 